\title{
THE IMPACT OF INTANGIBLE FACTORS ON THE EMPLOYEES OF EDUCATIONAL INSTITUTIONS
}

\author{
Ramūnas Vanagas \\ Audronė Urmanavičienè \\ Mykolas Romeris University, Lithuania
}

\begin{abstract}
The goal of this article is to explore the motivation and the factors for the motivation, to discuss the impact of intangible factors for the motivation of educational staff (teachers) for their work efficiency. In order to achieve these goals we have set the following tasks: to define the concept of motivation by analysing scientific literature; and to establish the determinant factors for the motivation of teachers. Motivation is a complex phenomenon, related to the promotion of behaviour, actions and efficient activities. Motivation of teachers is a part of the general strategy of a school, which is influenced by the headmaster, the administration of the school, the attitude of the staff and the created conditions for a teacher to work successfully and to apply innovative methods in their work and to feel responsible for the development of personality.
\end{abstract}

Keywords: educators', employee motivation, motivation, organisation.

\section{Introduction}

Every organisation which tries to achieve better work results tries to achieve maximum productivity of their staff. One of the optimum ways to achieve this is by motivating the staff. The majority of modern organisations understand that the motivation of staff is a methods of optimum use of human recourses and to creating a workforce which is loyal to the company. As the socioeconomic situation in Lithuania differs from Europe, and means that in non-foreign organisations staff motivation methods are applied by taking into account the cultural, ethical, political and economic differences.

Most managers in Lithuania understand motivation as encouragement by the means of monetary remuneration. In motivational systems that are used in Western countries, monetary remuneration is just one of the parts of the motivational system while other motivators are used as well, which are often more effective and cheaper than monetary. Unstable economy, emerging generational differences and disloyal employees amplify new problems which arise in organisations. According to the European study published by the international management and consultation company Hay Group, up to $43 \%$ of employees feel unmotivated or lack the means for proper performance at work (Re'em Y. 2011). These statistics challenge the management to change the motivational systems at their organisations. Increasingly more attention is given to non-monetary incentivisation of employees, and its impact for the organisation and staff. The main problem encountered by the management when 
trying to create a suitable motivational system is to establish methods of nonmonetary motivation and their influence for the results of the company (Armstrong, 2006; Atkinson, 1996; Felser, 2006). This determines the relevancy of this article.

The goal of this article is to analyse the impact of non-monetary motivation of the work efficiency of educational staff (teachers). In order to achieve this goal authors have set the following objectives: to establish the opinion of various authors on non-monetary motivation and its impact on the work efficiency of employees and to compare the theoretical findings with the results of an empirical research and to provide our conclusions. The following methods were used for this article: analysis of literature, analysis of documents, comparative method and the coordination of qualitative and quantitative research methods.

\section{Aspects of external and internal employee motivation}

Work efficiency in impacted by both material incentives (monetary bonuses etc.), and moral factors (liked activities, good relations with co-workers and the supervisor, etc.). Incentive is only efficient, when the incentivised believes that the incentive was determined by his/her corresponding efforts. Wage is still a motivator for many people because of the difficult economic situation and this method of motivation is especially efficient. All physical and mental efforts of employees are done for the wage, and the work results depend on the material interests of the employees - wage; e.g. monetary remuneration for the work (Franken, 2002; Gražulis, 2005; Luthans, 1998).

Besides the especially efficient means of motivation - wage, non-monetary motivation is also very important. Managers understand that for low-income employees' higher wage is an important factor in order to subsist, while for the people who earn higher than medium income money is not the primary motivator and they should be more interested in non-monetary motivation. During the economic crisis it is very difficult to motivate employees if they are motivated by higher wages. Therefore it is important to note how non-monetary motivation could be used during the crisis, because it either does not cost anything or costs very little (Gražulis, 2012; Bowditch \& Buono, 2005).

In order to explain the complex process of motivation and discover the model which explains the actions of person, which encourages work, two theories have emerged: Need Theory and Process Theory. Need Theory is centred on the needs of a human, which are the stimuli for the activities, which encourage a person to act, and an employee attempts to fulfil them. These processes were researched by A. Maslow, D. McClelland, F. Herzberg and other scientists. These theories describe the main motives which determine the activities of an employee, which lead to successful result. Process Theory attempts to explain not only the reasons why an employee decides to take a certain course of action, but the way the process of motivation works and what 
invokes specific behaviour. The most referred are these process theories: V. Vroom's Expectancy Theory, E. Locke's Theory of Goal Setting. D. Adams's Theory of Justice and Job Characteristics Theory. These theories centre on the goals, expectations and hopes of people and based on them the work process is being formed, which aims for satisfaction received from conducted activities (Marcinkevičiūtè, 2010; Diržytè, 2010; Greenhaus and Callanan, 2010; Houston, 2000 Maslow, 1943; Herzberg, 1968).

Methods of motivation could be very varied, depending on what they are targeting, while at the same time taking into account who provides them and what is their nature. In the opinion of the authors of the article a varied variety of these methods has to be ensured, because varied ways and forms of motivation are needed by the employees. In practice it can be observed that certain methods of motivation are not effective, because according to Carolyn (2004), Jazdauskaite (2004) and Kjeldsen (2012), every person is a personality and is motivated by different things. It is natural, that something that for one seems important and encourages to act and work more productively, could be a hindrance to another person. But, according to Blaskova (2009) and Žaptorius (2007), both material and psychological methods of motivation could be efficient when applied in combination. Hammill (2005) state that if only material methods of motivation are applied, then the long term incentivisation is not ensured. Therefore it is important to balance them appropriately, therefore we will examine each method for motivation in more detail, it significance and benefits for the employees of the company and the efficiency of its activities.

Motives which encourage a person to work are both internal and external. Literature specifies 3 manifestations of internal motivation: striving for mastery, desire to work and competitiveness (Marcinkevičiūtè, 2010; Rowley, 1996; Šavareikienè, 2008). Another important aspect is that actions determined by internal motivation are more determined, a person feels pleasure from these activities. The source for internal motivation the work itself, its substance - a person feels happy by performing certain tasks, he likes the activities he performs, and that the activities are successful - in other words - the joy comes from the activities themselves. At the same time others are motivated not by the process itself, but the result. Employee could be motivated by the fact that by performing a certain task he will receive recognition and respect, maybe he will be awarded the title of being the best in the organisation and will strive to achieve this recognition. It is important to stress that in the case of internal motivation an important role isplayed by personal values, such as integrity, responsibility, obstinacy, a desire to fit into a collective, teamwork etc. According to Šavareikiene (2008), one of the main factors for internal motivation is nurturing of self-esteem, the joy in interaction and partnership, and an opportunity to realize ones capabilities. The employee is motivated by interesting tasks, an opportunity to state ones opinion, to get involved into the 
creative and decision making process, also by the possibility to feel needed and heard (Adams, 2007; Byham, 2007; Žaptorius, 2007).

It is obvious that internal motivation is a basis for successful work of an employee, but at the same time it is a complex and a very individual process the supervisor has to be especially observant and intelligent and able to evaluate the abilities of every single individual and his/her input for the organisation and to direct his activities in a proper direction.

External motivation, as opposed to internal, is easily noticeable and easily implementable. External motivations are most commonly described as "activities, which are performed for external rewards or as a result of a wish to avoid punishment". It is formed from certain external incentives - rewards and punishments. Employee knows that his activities (a performed task) will be evaluated and he will be additionally rewarded, and strives to perform the task not only better, but also faster. It needs to be noted, that even if the task is not interesting or liked by the employee he will nevertheless try to fulfil it, knowing that he will be rewarded for it. Therefore it is conditioned not by the work itself, but initiated by the organisation: wage, good work conditions, flexible work schedule, status and recognition, praise, career, etc. (Re'em, 2011 Baršauskienè, Et al., 2010; Šavareikiené, 2008).

When summarising internal and external motivation it can stated that internal motivation promotes better results, because employees strive to achieve better results even when there is no rewards, while supervisors who only recognise external motivation achieve only short-term effect and fail to use the potential of their employees, their abilities to improve themselves and in this way expend the resources of the organisation.

When analysing methods for motivation such as proper organisation of work processes, interesting tasks, pleasant work environment, good relations with colleagues, respect and recognition - all of them could be described as nonmonetary motivation.

Herzberg (1968) presented the advantages of non-monetary incentives: in his two factor theory he noted, that the lack of money creates dissatisfaction and discomfort, but if this lack is negated, no long term satisfaction is created (Armstrong, 2006) - contrary to instances where non-monetary incentives are used. When evaluating motivational process, states, that when an employee is only motivated with money, he/she is not encouraged to improve, his creativity and responsibility is not being developed (Adams, 2007) - because of this reason loyalty to the organisation is lost, the employee could easily change his workplace for a more interesting and more difficult work, where he could improve oneself and could achieve recognition (Rowley, 1996; Higgins, 2000; Houston, 2000; Franken, 2002).

The importance of non-monetary motivation is shown if we explore the reasons why employees work: the work creates new challenges and stimulates them to take up new activities; employment provides them with new knowledge 
and develops personality; status and recognition; provides a possibility to satisfy the need for socialization, the possibility to implement their ideas (Žaptorius, 2007; Baršauskienè et al., 2010).

When taking this into account we can specify these methods of incentivising employees via internal motivation: giving them more responsibility; including employees into the decision making process; giving them opportunity to collectively analyse the problems of the organisation, and to suggest solutions; possibility for self-realisationby creating conditions and providing necessary means; the possibility to work a meaningful, interesting and indispensable job; the possibility to improve oneself and learn; autonomy, recognition and respect (Diržytė, 2010; Jadzauskaitè, 2004; Re'em, 2011; Šavareikienè, 2008).

Non-monetary methods for motivation could be described as a set of incentivising measures sponsored by an organisation applied to an employee by providing free services or goods, which are paid for by the organisation. Nonmonetary means of motivation paid for by the employee could be: means which ensure better work environment and microclimate at the organisation; means targeting the leisure and hobbies of the employee; means targeting the family of the employee (Rowley, 1996; Higgins, 2000; Houston, 2000; Franken, 2002).

Means of motivation related to the subject matter of work are hardest to implement but are one of the most effective - interesting and meaningful work, clear tasks, participation in activities of the company (possibilities to voice ones opinion, to participate in the decision making and to take certain decisions autonomously and independently), career opportunities and various other measures ensure internal satisfaction of the employee and actively motivates to work. These measures are given special attention and many authors stress their importance - specific work organization, and the setting the goals of an employee within the organization and others.

When discussing non-monetary motivation work-life balance is gets more attention e.g. possibility to balance work and personal life, personal needs (Baršauskienè et al., 2010). Here flexible work schedule gets more important role: the possibility to shorten the work week by transferring weekly work hours to a smaller number of work days, flexible time for the beginning, the end of work or the lunch break; work at home or other places by communicating with the organisation via internet or other means of communications; the possibility to split full time work to several employees. In work-life balance more attention is given to the lifestyle of a person, one hobbies, therefore services such as subscriptions to sports clubs and swimming pools located near the location of the organisation become a strong motivator - organisation in this way shows, that it feels it is important for the employee to feel well, despite the fact that this activity does not bring direct benefit for the company. The organisations attitude towards the family is essential, therefore the education of the employee's children in kindergartens and schools which are located near the location of the 
organisation, paid by the company is a strong motivator. When implementing life-work balance in organisation attention is also given to the creative potential of the staff. Because of this reason the companies grant employees sabbaticals and the opportunity to implement their ideas by using the resources of the company. There are many ways to create positive work-life balance, but it is created individually for every employee - by taking into account their needs, values and goals. It has been observed that employees who have the opportunity to balance their work and their personal life feel safer an less stressed, value their workplace, are more loyal, more motivated to work and are more satisfied with their work (Atkinson, 1996; Rowley, 1996; Higgins, 2000; Houston, 2000; Franken, 2002; Žaptorius, 2007).

Video games, which are used by companies in their activities to formulate tasks and evaluate them could be described as one of the most recent trends in methods of motivation, could be described as method of motivation related to the subject of the work. Because evolving modern technologies these games are used in a creative manner. Means of motivation used in an organisation depend from the supervisor - some of them choose usual methods of organising work, while others try to find interesting and new ways of shaping the methods of work. It is difficult to establish which of these methods are the most effective, because they are also influenced by factors such as the environment within the organisation, branch of activities, employees of the company and the relationships within the company. The increasing number of various methods of motivation shows that it is a varying process, which is conditioned by the environment (Higgins, 2000; Houston, 2000; Franken, 2002; Žaptorius, 2007).

It could be stressed that for a successful work of a school a reasonable coordination of the desires of teachers, needs and the facilities of the organisation, selection of suitable methods for motivation is essential, because as the conditions of life change, the needs and interests of employees change as well. If the same methods are applied over and over they become inefficient, therefore the system of motivation has to be flexible and the capability to react to individual and external factors of teachers, because only a successful teacher could enjoy his work and feel responsible for a full and meaningful education of personalities.

\section{Survey of educators' motivation}

Empirical survey of educators' motivation was conducted in 2014. Anonymous instantaneous written survey has been used on the teachers of Vilnius schools. A questionnaire has been used with sociodemographic questions and questions regarding the motivational factors, as well as an instantaneous survey. Response rate for the questionnaires $-87 \%$. One of the main goals of the research is to find relation between the data. In order to achieve this goal correlation analysis for motivation factors has been conducted. Correlation is determining the relation between an attribute, its direction and its 
strength. When conducting correlation analysis it is only required to establish the existence of a relation between two factors and to determine the strength of its qualitative characteristic. In order to determine the relation between the data the Pearson product-moment correlation coefficient has been used, which is calculated by using function Correlate in SPSS Statistic software.

With the questions submitted in the empirical survey it was attempted to establish the importance of intangible factors, such as means of motivation to educators. When evaluating the general satisfaction of educators with intangible motivational factors the following indicators were determined: the students' motivation to learn; achievements of students; interesting subject-matter; possibilities for self-realisation; cooperation with parents (carers); respect and trust of students; career opportunities; possibilities to improve one's qualifications; hospitable psychological climate; respect and trust of the superiors.

Just like with the case factors of material motivation, respondents evaluated each questions in a scale from 1 to 5 by stating their importance: from "very unimportant" to "very important". After calculating the averages the results show that the possibilities to increase ones qualifications motivates the least $(3,72)$, while the achievements of students motivates the most $(4,50)$ (see figure $1)$ :

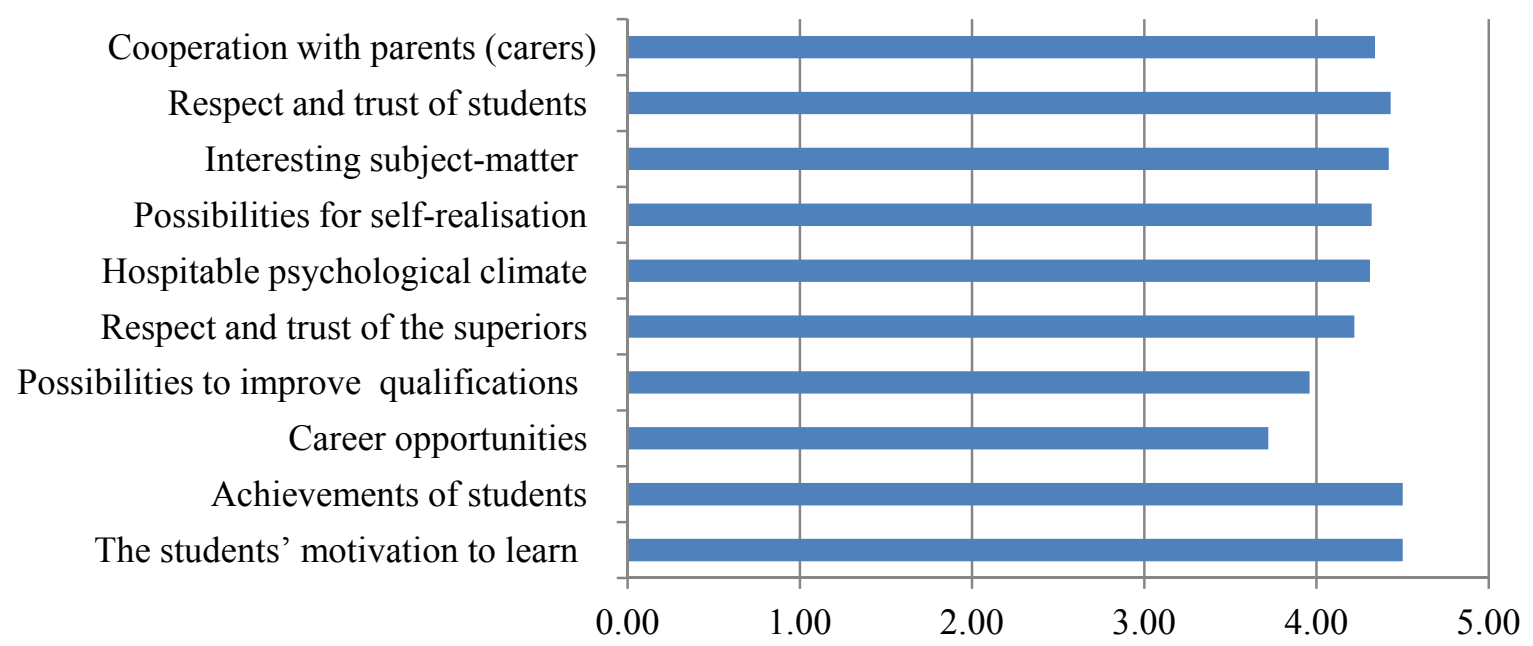

Figure 1. Average estimates for intangible motivation factors

Total average for all factors is 4,27 and it proves that intangible factors are very important for teachers, while the evaluation of material factors was slightly lower $-3,96$. Evaluation of total satisfaction of educators with intangible factors at their school equals to an average evaluation of 4,15 . When compared to an average evaluation of the previous question $(4,27)$, the average evaluation 4,15 shows that teachers show insubstantially lower satisfaction of intangible motivation at their school when compared to the one they desire. When researching general satisfaction of teachers with the factors of intangible 
motivation (Y), we tried to establish if a stochastic correlation between the selected ten factors. In this way paired correlation analysis (Y) has been conducted with each factor $x_{1}-x_{10}$.

Coefficients presented in the figure 2 show that there is a positive correlation between specific factors of motivation and general satisfaction of teachers for intangible motivation factors. We see that the correlation is strong from relatively high coefficient. "Interesting subject -matter" and "Students' motivation to learn" are the most influential in terms of factors determining general satisfaction. It could be stated that these two factors are closely interrelated: the more teacher loves his work and is selfless the more creative and interesting his he becomes for the students. And vice versa - the more children are interested in a particular subject, the more teacher is stimulated to brace up, to improve himself and to find new methods of teaching. The factor least correlating with the general satisfaction is the "Respect and trust of the superiors" (see figure 2), which shows how a specific factor influences general satisfaction of intangible factors.

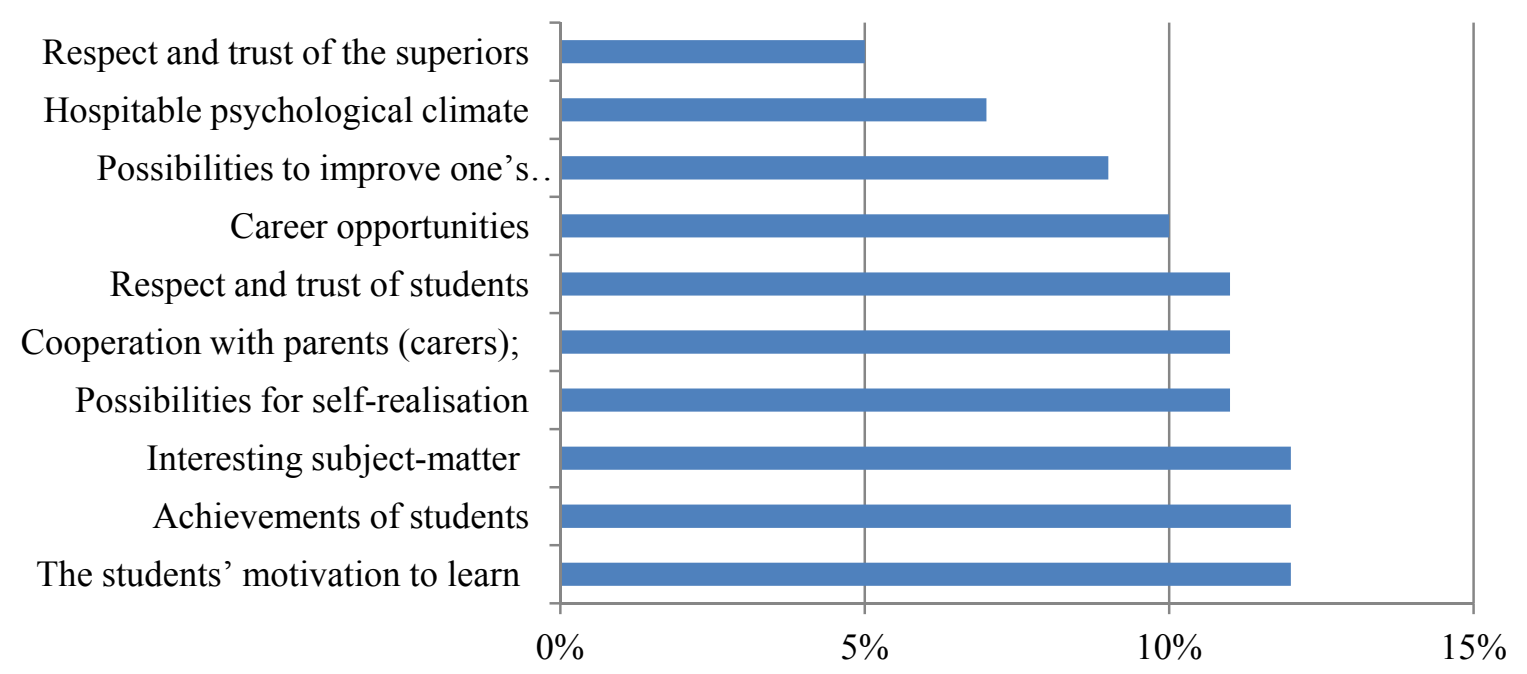

Figure 2. Influence of specific factors for general satisfaction from intangible factors, $\%$.

From this diagram can be seen that all the factors are distrubuted relatively evenly. We can make a conclusion that the input of each of these factors to the general satisfaction is signifcant and almost equally important.

\section{Conclusions}

1. The process of motivation is an activity which incentivises a person to act in a certain way, by creating satisfaction for the employee and taking into account the needs and the goals of the person within the organisation. The behaviour of employees is influenced by both internal and external motivational tools, but it is acknowledged that internal motivation is more 
efficient, because people with this motivation try to complete tasks even if there is no reward.

2. Non-monetary motivation is described as an activity during which nonmonetary tools for improvement of activities of an employee are used. To summarise all non-monetary methods of motivation they could be separated into three groups: non-monetary methods of motivation financed by the organisation; social non-monetary incentives and work-subject related methods of motivation.

3. When researching intangible factors, ten factors were described, which constitute general intangible motivation. Their average evaluation distributed from 3,72 to 4,51 (scale from 1 to 5). Therefore it can be stated that all of these factors are significant for teachers. Highest evaluated factors were "Students' achievements" and "Students' motivation to learn". After conducting correlation analysis it was established that general satisfaction from intangible factors were determined by all factors (correlations of 7 factors is strong, while others are average). All evaluations, averages and correlations show that intangible factors are more important for teachers than non-material. All data - evaluation of averages and correlation with general satisfaction process that the crucial motivational factors in the teachers work are intangible. Also this research shows that intangible factors seem more significant to the teachers themselves, especially students' motivation and the will to learn.

\section{References}

Adams, J. (2007). Managing people in organisations: contemporary theory and practice. Basingstoke: Palgrave Macmillan.

Atkinson, J. N., Feather, N. T. (1996). A theorie of achievement motivation. New York: Wiley.

Armstrong, M. A. (2006). Handbook of human resource management practice. London: Philadelphia (Pa.).

Baršauskienè, V., Almonaitienè, J., Lekavičienè, R., Antinienè, D. (2010). Žmonių santykiai organizacijose. Kaunas: Technologija.

Barkauskaitè, M. (2001) Mokytojų kvalifikacijos kèlimas- nuolatinio mokymosi pagrindas. Pedagogika. Vilnius: VPU.

Byham, W. C., Cox J. (2007). Igalinimo žaibas - kaip pagerinti kokybę, kaip padidinti našuma ir darbuotoju pasitenkinima. Vilnius: Rgrupè.

Blaskova, M., Gražulis, V. (2009). Motivation of human potential: theory and practice. Vilnius: Mykolas Romeris University.

Bowditch, J.L., Buono, A.F. (2005). Primer on Organizational Bahavior. New York: John Wiley \& Sons.

Carolyn, C. (2004). What Motivates Staff?//Family Practice Management, Downloaded from:http://www.aafp.org/fpm/2004/1100/p54.html.access (2015.01.03).

Diržytė, A., Patapas, A., Mikelionytė, R. (2010). Viešojo ir privačiojo sektorių vadovų darbo motyvacijos ypatumai. Viešoji politika ir administravimas. Vilnius: Mykolo Romerio universitetas. 


\section{SOCIETY. INTEGRATION. EDUCATION. Volume II}

Felser, G. (2006). Motyvacijos būdai: asmens sèkmę lemiantys faktoriai, praktinis psichologijos panaudojimas. Vilnius: Alma littera.

Franken R.E. (2002). Human motivation. Belmont: Wadsworth//Thomson Learning.

Gražulis, V. (2005). Motyvacijos pasaulis- jo supratimo keliai ir klystkeliai. Vilnius: Ciklonas.

Gražulis, V. ir kt. (2012). Darbuotojas organizacijos koordinačiu sistemoje: žmogiškojo potencialo vystymo perspektyvos. Vilnius: Mykolo Romerio universitetas.

Greenhaus, J. H., Callanan, G. A. ir kt. (2010). Career management. USA: Sage Publications.

Hammill, G. (2005). Mixing and Managing Four Generations of Employees // Magazine Online: Downloaded from: http://www.fdu.edu/newspubs/magazine/05ws/ generations.htm, access (2014.12.05).

Herzberg, F. I. (1968). One More Time, How Do You Motivate Workers. Harvard Business Revie.

Higgins, E. T. (2000). Social cognition: Learning about what matters in the social world. European Journal of Social Psychology, 30, 3-39.

Houston, D.J. (2000). Public - Service motivation: A Multivariate test. Journal of Public Administration Research and Theory. Downloaded from: http://jpart.oxfordjournals.org/ content/10/4/713.full.pdf + html. access (2014.12.20).

Jadzauskaité, V. (2004) Darbuotojų motyvacija: kaip palengvinti pavaldinių kelionę akmenuotu keliu. Vadovo pasaulis Nr. 4.

Kjeldsen, A. M. (2012). Dynamics of Public service motivation. Department of Political Science and Government. PhD Dissertation. Denmark: Aarhus University.

Luthans, F. (1998).Organizational behavior. Boston:IrwinMcGraw-Hill.

Marcinkevičiūtè, L. (2010). Darbuotoju motyvavimo modeliai: teoriniai ir praktiniai aspektai. Akademija, Kauno r.: Lietuvos žemès ūkio universiteto Leidybos centras.

Maslow, A.H. (1943). A theory of human motivation .Psychological Review.

Re'em, Y. (2011). Motivating public sector employees: an application-oriented analysis of posibilities and pactical tools. Working papers. Hertie school of governance. Downloaded from: http://www.hertie-school.org/fileadmin/images/Downloads/ working_papers/60.pdf. access (2014.12.15).

Rowley, J. (1996). Motivation and academic staff in higher education. Quality Assurance in Education. Downloaded from: http://www.emeraldinsight.com/doi/pdfplus/ $10.1108 / 09684889610125814$.

Šavareikienè, D. (2008). Motyvacija vadybos procese. Šiaulių universitetas.

Žaptorius, J. (2007). Darbuotojų motyvavimo sistemos kūrimas ir jos teorinè analizè. Filosofija. Sociologija. Vilnius: Lietuvos mokslų akademijos leidykla. 